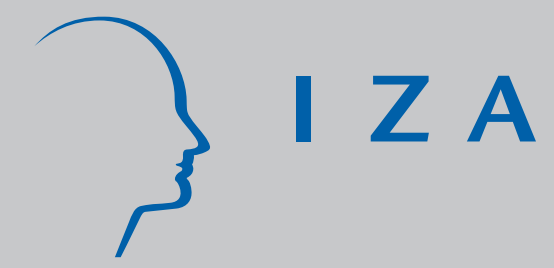

IZA DP No. 352

Unions and Plant Closings in Britain: New Evidence from the 1990/98 WERS

J ohn T. Addison J ohn S. Heywood

Xiangdong Wei

August 2001 


\title{
Unions and Plant Closings in Britain: New Evidence from the 1990/98 WERS
}

\author{
John T. Addison \\ Moore School of Business, University of South Carolina and IZA, Bonn \\ John S. Heywood \\ University of Wisconsin at Milwaukee and University of Birmingham \\ Xiangdong Wei \\ Lingnan University Hong Kong, and University of Birmingham
}

Discussion Paper No. 352

August 2001

\author{
IZA \\ P.O. Box 7240 \\ D-53072 Bonn \\ Germany \\ Tel.: +49-228-3894-0 \\ Fax: +49-228-3894-210 \\ Email: iza@iza.org
}

This Discussion Paper is issued within the framework of IZA's research area Mobility and Flexibility of Labor Markets. Any opinions expressed here are those of the author(s) and not those of the institute. Research disseminated by IZA may include views on policy, but the institute itself takes no institutional policy positions.

The Institute for the Study of Labor (IZA) in Bonn is a local and virtual international research center and a place of communication between science, politics and business. IZA is an independent, nonprofit limited liability company (Gesellschaft mit beschränkter Haftung) supported by the Deutsche Post AG. The center is associated with the University of Bonn and offers a stimulating research environment through its research networks, research support, and visitors and doctoral programs. IZA engages in (i) original and internationally competitive research in all fields of labor economics, (ii) development of policy concepts, and (iii) dissemination of research results and concepts to the interested public. The current research program deals with (1) mobility and flexibility of labor markets, (2) internationalization of labor markets and European integration, (3) the welfare state and labor markets, (4) labor markets in transition, (5) the future of work, (6) project evaluation and (7) general labor economics.

IZA Discussion Papers often represent preliminary work and are circulated to encourage discussion. Citation of such a paper should account for its provisional character. 
IZA Discussion Paper No. 352

August 2001

\section{ABSTRACT \\ Unions and Plant Closings in Britain: New Evidence from the 1990/98 WERS*}

In this paper we exploit the longitudinal element of the 1990 and 1998 Workplace Employee Relations Surveys for Britain to investigate the effect of unionism on establishment closings. Contrary to both recent U.S. research and British work using information from the earlier workplace surveys, we find a robust positive association between two measures of unionism - union recognition for collective bargaining purposes and union coverage - and plant closings. This association survives the incorporation of very detailed industry controls but is driven by plants that are parts of multi-establishment enterprises. There appears to be little or no statistically significant association for single plant enterprises. In explaining our findings, we address their consistency with the widely perceived reduction in the "disadvantages of [British] unionism" in recent years.

JEL Classification: J51, J65

Keywords: $\quad$ union recognition, union coverage, plant closures, WERS

John T. Addison

Department of Economics

University of South Carolina

Columbia, SC 29208

U.S.A.

Tel.+ (001) 803-777-4608

Email: ecceaddi@darla.badm.sc.ed

\footnotetext{
* We thank, without implicating, Barry Hirsch and Paulino Teixeira for helpful comments on an earlier draft of this paper.
} 


\section{Introduction}

The effect of unions on establishment closings is an important but poorly developed theme in empirical labor economics. This is unfortunate because the association is important to explanations of union impact on economic performance and as a potential explanation for the ongoing decline in union membership. Both topics remain clouded in part because of the dearth of evidence of union impact on establishment closings. In the present paper, we assemble data from the British Workplace Employee Relations Surveys for 1990 and 1998 to investigate the issue. We obtain very different results from those reported in the most recent U.S. and British studies, finding a robust positive relationship between measures of unionization and establishment closings in the private sector. This positive association is driven by plants that are part of multi-establishment enterprises. In single-establishment firms, the union coefficient is negative but usually not statistically significant. The empirical distinction between types of establishment is likely to be important on theoretical grounds, but policy shifts may also cast a long shadow in the light of legal changes during the decade of the 1980s and the early 1990s that served $\mathrm{v}$ weaken union bargaining power.

The plan of the paper is as follows. In the next section, our review of the sparse empirical literature on unions and plant closings is stiffened by broader detail on union effects on establishment performance (based on samples of survivors). After that, we offer some applied theoretical conjectures on the expected associations. A brief review of the data is then followed by presentation of our detailed findings including a replication of the principal British study by Machin (1995). An interpretative section concludes. 


\section{The Empirical Literature}

There is an extensive literature examining union effects on productivity, profitability, investment, and employment for both the United States and the United Kingdom. This literature may serve, in part, to suggest the direction of union influence on establishment longevity. U.S. productivity studies are summarized in Addison and Hirsch (1989), and their British counterparts in Metcalf (1994). The broad conclusion of the U.S. research is that union productivity effects even where positive are small relative to the union wage premium. The British evidence points more consistently to adverse union productivity effects, albeit with the caveat that these have been attenuated in recent years.

Almost all U.S. studies point to negative union effects on profitability irrespective of the profit measure deployed (see, for example, Addison and Hirsch, 1989; Hirsch, 1991; Becker and Olson, 1992; Bronars, Deere, and Tracy, 1994). The dispute in the early U.S. literature as to whether the profit effect is confined to concentrated sectors (cf. Karier, 1985; Clark, 1984) still lingers, but it is now recognized that union wage gains accrue from quasi rents that are not confined to the returns from imperfect competition (Hirsch 1991). Likewise, almost without exception, the British studies report that profitability is lower in unionized establishments (Metcalf, 1993; Metcalf, 1994). That said, there is again the suggestion that such adverse union effects have dissipated through time. Indeed, Machin and Stewart (1996) claim that such effects are now only observed in plants with the closed shop.

Taken in conjunction with supporting evidence on the union wage premium, the U.S. evidence on investments in physical capital generally falls in line with the pattern of findings reported earlier, and points to consistently lower investment in unionized 
regimes (e.g. Fallick and Hassett, 1999; Hirsch, 1991, 1992). Time-series studies for Britain also indicate negative union effects (e.g. Denny and Nickell, 1992), even if there is again evidence of a weakening in such effects in the 1980s compared with previous decades (see Metcalf, 1994, p. 151). U.S. research has also found rather strong evidence that unionization adversely impacts $R \& D$ investment (Hirsch, 1991). But this indication of union rent seeking acting as a tax on intangible investment is not replicated in the sole U.K. study. Thus, Menezes-Filho, Ulph, and Van Reenen (1998a) report that the negative correlation between union density/recognition and $R \& D$ intensity that is observed in cross section and panel data, for plants and companies respectively, disappears when one accounts for age effects and the availability of innovative activity in the relevant industry. Interestingly, since the authors also run parallel tests for U.S. data that confirm the earlier U.S. results, they conjecture that the disparities in findings between the two countries reflect British unions placing greater emphasis on employment relative to wages than their U.S. counterparts (see section 3, below). That said, there are alternative explanations including the notion that union power was sufficiently dented by the Thatcher reforms as to bring about the result, even if there is disputation as to the course of the union wage premium through time. In other words, the theme of a "decline in the disadvantages of unionism" (the expression is attributable to Oulton, 1990) through time might also be reflected in the $R \& D$ outcome indicator.

Finally, when one turns to the evidence on employment change, U.S. findings generally suggest that employment growth is lower (and employment contraction is greater) in the union sector (e.g. Leonard, 1992; Linnemann, Wachter, and Carter, 1990; Dunne and Macpherson, 1994). Only Bronars and Deere (1990) report inconclusive 
evidence when investigating the employment effects of union representation elections. For their part, British studies also consistently report lower growth and/or greater shrinkage in the union sector (Blanchflower, Millward and Oswald, 1991; Fernie and Metcalf, 1995).

In sum, with the exception of one British study dealing with intangible capital formation, union effects on productivity, profitability, investment, and employment change are generally unfavorable. It might appear reasonable in these circumstances to anticipate higher rates of business failure in union regimes. Yet, as we shall see, there is little concrete evidence of this in the few published studies of plant closings. ${ }^{1}$

Beginning with the U.S. evidence, although there are case studies pointing to high union labor costs as a major reason for plant closings during the 1980s (see Gerhart 1987), the two principal econometric studies fail to detect higher rates of attrition in unionized regimes. Thus, in a sectoral analysis based on establishment data from the 1977 and 1982 Census of Manufactures micro-data files, Dunne and Macpherson (1994) report that sectors with high union membership did not experience significantly greater employment loss due to plant closings than their less unionized counterparts, controlling for the price-cost margin and establishment size. $^{2}$ (As noted earlier, the authors' parallel analysis of sectoral contraction and expansion rates does suggest, however, that more heavily unionized sectors do downsize more and have (marginally) lower growth, other things being equal.) A more comprehensive U.S. analysis by Freeman and Kleiner (1999) basically confirms this finding from the sectoral aggregates. Freeman and Kleiner address the issue using three data sets: a sample of firms/business lines from the COMPUSTAT I and II files, 1983-90, supplemented with union density information from Hirsch (1991); 
information on displaced workers from the Current Population Survey (CPS) displaced worker supplements for 1994 and 1996 linked to control samples from the CPS out-going rotation group, 1991-95; and information on the rate of plant closure in union and nonunion regimes from the files of the Federal Mediation and Conciliation Service (FMCS).

We focus here on the authors' analysis of the union impact on insolvencies, while entering the qualification that insolvencies and closings are not synonymous. Freeman and Kleiner's final sample comprises 633 business units $(319$ firms and 314 business lines) of which 126 became insolvent (67 firms and 59 terminated business lines). Probit estimates of union effects are presented for the combined sample and reveal no evidence that the covariates had an effect on firms that differed materially from their effect on business lines. For a specification that includes just a union dummy and union density (plus dummies for whether the observation was a firm or a line of business), it is found that union presence is negatively associated with the likelihood of failure but that as the union presence increases the firm/business line is more likely to fail. Adding in controls for firm age, sales, and a vector of industry characteristics (viz. concentration ratios, growth rate of sales, import penetration rates, and bankruptcy rates) reduces the effect of union presence but not that of union density, each remaining statistically significant. Finally, replacing the union variable(s) with the categorical measures of low, medium, and high density indicates that only the last category is associated with greater rates of insolvency, compared with no union presence. Irrespective of specification, however, insolvencies are only higher than in non-union regimes where union density is at or above 60 percent, a level that is twice the average unionization rate of the sample. Ancillary regression analysis of profitability suggests that unions are associated with lower 
financial performance, although on this occasion the most negative effect are observed at lower levels of union density. ${ }^{3}$

Since the insolvency rates might reflect survivability bias - namely, a union sample that is predominantly made up of long-lived survivors - Freeman and Kleiner use the FMCS data to informally address the issue of whether newly unionized firms close more frequently than other firms. For the interval, 1986-93, it is found that just 341 out of 10,783 certification elections (and 3,009 out of 168,945 dispute cases) resulted in plant closures. Expressed as rates of closure, these values compare favorably with estimates of business failures from the Annual Surveys of Manufactures, averaging 3.4 percent per year between 1974 and 1978. Equating the latter with average rates of plant closure in the absence of new unionism, Freeman and Kleiner (1999: 525) conclude that there is "virtually no union effect on closure of new plants" (see also Freeman and Kleiner, 1990).

Freeman and Kleiner use the CPS data to estimate the individual's probability of being displaced, the data set providing no information on firm size or establishment characteristics. The analysis first uses the outgoing rotation sample to estimate the probability of unionization, and then uses this equation to predict the proportion of workers who should be union members in the displaced worker sample. Next control groups (of non-displaced workers) are assembled from the rotation group which are combined with the displaced worker sample to investigate the effect of union membership on the probability of job loss by reason of plant closure. These two exercises reveal that the proportion of union workers among the displaced population is almost exactly predicted by their characteristics and that the probability that a worker will be 
displaced by plant closure - or indeed for any other reason - is not materially affected by his or her union status.

The sole published study for Britain is by Machin (1995), and uses data from the 1984-90 panel sample of establishments from the Workplace Industrial/Employee Relations Surveys. Machin exploits the longitudinal element from the 1984 Workplace Industrial Relations Survey and the 1990 Workplace Employee Relations Survey (WERS) to identify establishments that were in the 1984 survey but subsequently closed down. (We shall use the same element from the 1990 survey and the successor 1998 WERS to identify establishments from the 1990 survey that failed sometime in the course of the following eight years. We shall also replicate Machin's basic specification using these more recent data.) Machin's full sample comprises 704 trading sector establishments of which 87 appear to have closed down between the two surveys 'appear' in the sense that while 70 closures could definitely be so classified the remaining 17 establishments could not be traced. Machin presents five probit estimates of plant closure and in each case computes the marginal union effects. In his most parsimonious specification, the plant closure dummy is regressed on the presence or otherwise of a trade union recognized for collective bargaining purposes. The coefficient estimate for union recognition is negative and significant at the .10 level. Establishments with union recognition emerge as some 4.8 percent less likely to have failed over the six-year sample period. A second specification adds controls for establishment employment size, the share of manual employees in the workforce, single-plant firm status, and manufacturing industry. The effect is to reduce in absolute size the magnitude of the union coefficient estimate, which is no longer statistically significant from zero. The effects of the other 
covariates are all are well determined other than for the share of manual workers: establishment size and single-plant operations being associated with a smaller likelihood of closure, and conversely for manufacturing industry establishments. A third specification adds two inverse measures of establishment performance, namely, below average financial performance and a low degree of capacity utilization. (Although both are positively signed, only the latter variable is statistically significant.) Their inclusion serves to increase the absolute value of the union coefficient estimate, although it remains statistically insignificant from zero. Two final specifications distinguish between the type of union that is recognized for collective bargaining purposes. In circumstances where any manual unions are recognized the union coefficient estimate is positive but statistically insignificant. For non-manual unions the recognition variable enters negatively but again is insignificantly different from zero.

Since British research has suggested that union premia have been highest in closed shop situations, Machin also tests whether such regimes were associated with higher risk of closure over the sample period. They are found not to be, again irrespective of type of union. Similarly, the basic result that unions have no discernible impact on closings is shown to be robust to the exclusion of the 17 less than clear-cut closings, and to the inclusion of one-digit industry dummies and a set of age-of- establishment dummies.

Machin thus concludes that he can reject the null hypothesis that closure rates are higher in unionized establishments. He further asserts that there is no evidence to suggest that unions imperil firm survival in the long run, or that plant failures have played a part in the waning fortunes of British unionism, 1984-90, when the proportion of workers 
covered by a collective agreement fell from 71 percent to 54 percent and density declined from 54 percent to 38 percent.

\section{Theoretical Conjectures}

A body of theoretical research does have as an implication that union rent-seeking should lead to greater rates of plant closure in union regimes. This is, for example, the long-run implication of Lazear's (1983) model of sustainable monopoly unionism and, more directly, that of Grout (1984) based on the notion of union appropriation of the quasirents to long-lived tangible and intangible capital. That being said, one must be cautious in attributing a finding of lower investment in unionized firms (and implicitly greater rates of failure even under efficient bargains) to unions. While it is true that without a union there can be no conflict over the division of the surplus, this conflict does not lead in and of itself to sub-optimal investment. There must be other factors at work as well. As Addison and Chilton (1998) have shown, these factors include not just union myopia but also the firm's patience and the durability of its capital. The contribution of these factors to lower levels of investment typically observed in union settings has not been modeled. It is also true that the incorporation of other theoretical insights, and in particular the strategic aspects of R\&D rivalry under oligopolistic competition (Menezez-Filho, Ulph, and Van Reenen, 1998b), may mean that unions can increase the firm's incentive to innovate, but the implications for standard models of union wage and employment determination remain opaque. The bottom line is that the theory is ambiguous on the dynamic implications of union rent-seeking on plant closings, even if there is undoubtedly an investment problem in union regimes. 
Not surprisingly therefore, the applied treatments considered earlier have tended to skirt these theoretical issues. Thus, Freeman and Kleiner (1999, p. 512) simply argue that unions care about the employment prospects of their membership and will make concessions to keep the firm afloat. Rational unions, we are told, should not push firms to the edge of bankruptcy, and will grant wage concessions to sustain them (see also Kuhn, 1986). Freeman and Kleiner do acknowledge that bargaining failures (induced by suboptimal information disclosure) and maintenance of the standard rate may on occasion be sufficient to generate differential failure rates between unionized and nonunion plants. Yet, they insist that in general unions are not so foolish as to force organized firms out of business - their rationality being reflected in their organization of firms to begin with that have sufficient economic rent to deflect the probability of long-run business failure. Therefore, one should not expect to observe a positive association between union presence and bankruptcy, other things being equal.

Note, however, the evidence of Curme and Kahn (1990) that U.S. workers discount the value of pensions and deferred compensation in the face of increasing risk of firm insolvency. They report that a greater risk of firm bankruptcy leads to a heightened emphasis on current earnings and a consequent reduction in pension coverage. Moreover, for workers who do have pensions, a rise in probability of closure steepens the tenure-earnings profile rewarding insiders. Such evidence highlights the potential role that insiders might play in the face of an uncertain future to actually raise the current costs of firms in distress.

In light of the above, we would hazard some informal conjectures of our own that incorporate the concessions argument in association with the empirical finding from the 
British study by Machin (1995) that single-plant establishments have lower rates of closing. In particular, the concessions argument might be modified to reflect the status of firms as either multi-plant or single-plant entities. The availability of more generous severance packages and transfer rights (by seniority) in multi-establishment entities might make workers, and insiders in particular, less prone to make concessions than their counterparts in single plant firms. ${ }^{4}$

More generally, one might formulate a calculus of plant closing that emphasizes the benefits and costs: plants are more likely to close as the closing benefits rise and as the closing costs fall. Single-establishment operations can be viewed as having greater closing costs as they involve the exit of the firm. Plants with greater flexibility and lower production costs - as proxied by, say, the share of female employees and the proportion of workers on fixed-term contracts - should have lower closing benefits and be less likely to close. Returning to the union, a single establishment closing means that union workers will with certainty lose their jobs, so that the union may be prepared to grant concessions. These may range well beyond those available in non-union establishments, if we posit that a collective response by workers is likely to be more successful and circumstances in which there is more room to cut rents. Although the latter considerations also obtain in union regimes that are part of multi-establishment operations, there are countervailing influences: not only are union members likely to have transfer rights to other units of the enterprise but also the ongoing firm is more likely to fulfill its contractual and legal requirements covering severance pay, pensions, and other fringes to which members might be entitled. In short, the costs of establishment closure to the union might be lower 
in the case of multi-establishment undertakings and as a result the concessions it offers much attenuated compared with those made in single-establishment firms.

Perhaps counter intuitively, the end-game phenomenon (see Lawrence and Lawrence, 1985) may also support the notion that it is more costly to close singleestablishment undertakings. This is because the end game acts as an exit cost making closure less likely and/or delaying closure. If management expects a concessionary response, it may announce the possibility of closure and thereby capture the concessions that reduce the likelihood of closure. If management instead expects an end game, as the evidence from Curme and Kahn (1990) might suggest they should, the announcement of potential closure is likely to be delayed as long as possible to minimize the exit cost. Where the union has access to plant performance data, management may well take actions to prolong the life of the plant to avoid the exit. This again could serve to lower the likelihood of closure.

Since we are looking at the U.K., there exists the overlay of anti-union legislation. In a general sense, the implied attenuation of union bargaining power - widely suggested by the British literature - might be expected to have reduced any positive effect of unions on plant closings, yielding a continuation of Machin's (1995) results, only more so. On the other hand, the weakened status of unions may make plant closing easier as the union has fewer political and economics resources with which to oppose the closing. Manning (1993) has argued that one element of the union reforms in Britain - specifically the 1984 requirement for pre-strike ballots - may have led to a union loss of influence over employment (if not necessarily over wages on the grounds that wages unlike closings affect all workers equally) and to more plant closings. The argument is straightforward: 
in multi-plant enterprises, unions may keep open unprofitable plants by the threatening to strike profitable plants. The need to ballot members destroys the credibility of this mechanism because workers whose jobs are not in jeopardy will not vote for a strike. It is of course also possible that the decline in union strength more broadly may have allowed the substitution in double breasted enterprises of the output of non-union plants for union plants. This development might of course be conceptualized as sub-optimal, with employers taking the opportunity to recast the organization of the firm in a direction that favors profitability over the joint surplus. Be that as it may, the result might be to produce a positive association between the measure of unionism and plant closings in specifications controlling for single establishments (where no substitution is available) where none was discernible before. (For an early U.S. case study of the flow of capital and output from union to non-union establishments within firms, see Verma 1985.)

\section{Data}

The main data used in this study are taken from the British 1990 Workplace Employee Relations Survey (WERS), and from a trawl survey that served as a first step in the construction of the separate panel component of the 1998 WERS (see Millward, Bryson, and Forth, 2000). The WERS is a long-standing government-funded establishment survey aiming at mapping out the changes in industrial relations practice in Britain. The 1990 WERS was the third such inquiry in a series of surveys initiated in 1980. It covers a total of 2,061 establishments (plants) with 25 or more employees in England, Scotland and Wales. Establishment size-related weights are also provided for the data, so that the sample can be made nationally representative after weighting. 
For its part, the trawl of the 1990 WERS establishments was conducted for the purpose of selecting a sample for a panel survey alongside the 1998 WERS and identifies the on-going status of the 1990 establishments. The trawl confirms that of the 2,061 establishments, 222 had closed by 1997/98, while 1,803 remained in operation ${ }^{5}$ and 36 were no longer traceable. Accordingly, our initial useable sample comprises 2,025 establishments including the 222 failures. For the purposes of this empirical inquiry, we necessarily focus on for-profit organizations. This private-sector restriction reduces the sample to some 1,326 establishment observations.

Our dependent variable is a dummy variable that takes the value 1 if the establishment closed between the two survey dates. Due to the dichotomous nature of the dependent variable, probit estimation is employed for all regressions so as to ensure predicted probabilities within the zero-one bound and eliminate heteroskedasticity problems associated with linear estimation.

We use two union variables: union recognition and union coverage. The former measure is a dummy variable indicating whether or not the establishment has a written agreement recognizing unions (either manual or non-manual) for purposes of negotiating pay and conditions of employment. The latter measure is a continuous variable indicating the percentage of employees covered by the collective bargaining agreement. We prefer these constructs to the conventional union density measure, also available in the WERS, as we believe they are more closely linked to the union influence within an establishment. As a practical matter, however, the results reported below were consistent across all three union measures. ${ }^{6}$ 
We also constructed a number of other independent variables to control for establishment heterogeneity. These include in addition to establishment status, size, age, and workforce composition, a wide variety of other variables designed to capture industrial relations factors (such as representative participation, financial participation and disclosure, employee involvement schemes, and the climate of industrial relations more generally), workplace flexibility, technology, ownership, and competitive position, inter al. In addition, given the standard problem of union endogeneity, we include a much more detailed set of industry dummies than are usually deployed in studies of this nature. Because detailed industry dummies are not provided as a matter of course with the WERS, we had to contact the data archive for the four-digit industry affiliation for each establishment. At the most detailed level, we employ a total of 93 industry dummies. Definitions of the all the variables used and their means/standard deviations are provided in Table 1.

\section{Estimation}

Our estimation strategy builds up an increasingly complete set of controls to examine whether a robust association between unions and plant closure can be identified. Columns 1 and 2 of Table 2 provide results for a parsimonious specification in which the probability of plant closure depends on unionism and a narrow set of firm characteristics. Of the latter, it can be seen that large establishments are less likely to close than their smaller counterparts, all else equal. Furthermore, establishments having larger shares of female employees also appear less likely to close. Given the lower labor force attachment of many females, and the fact that they often work part-time, this association 
might be indicative of greater flexibility among plants employing them in greater numbers. Confirming earlier work (Machin, 1995, Table A.1), single establishment firms are less likely to close as well. Yet, in circumstances where unions are recognized or as union coverage increases, the probability of closure increases over the period in question. Note that that the estimations do hold constant the broad industry affiliation of each plant.

Given the parsimonious set of controls deployed thus far, the union variables may of course be capturing other aspects of the establishments that correlate with the closure probability. To examine this possibility, columns 3 and 4 of the table augment the previous specification with a very wide range of additional potential determinants. The broad industry dummies remain in the specification. As a matter of fact, the additional arguments generally do not take statistically significant coefficients. It now appears that firms with larger shares of manual workers are more likely to close, while the previous results pertaining to the effects of female composition and establishment size are much attenuated. But despite the addition of the many - and possibly collinear - new controls, the results for the union variables remain largely unchanged. If anything, the finding for union recognition is now slightly stronger than before, increasing in both magnitude and level of statistical significance. In short, the prior finding that union establishments were more likely to close in Britain over the 1990s persists.

We next further augment our estimations to include as detailed a set of industry dummies as makes sense given the size of our sample. In most cases this is the relevant 4 digit disaggregate dummy but for the smallest sample sizes it is the slightly more aggregate 3-digit dummy. The outcome is an estimation that includes 93 industry 
dummies as well as the two-dozen controls. At issue here is the simple point that what has up till now appeared as a distinct union effect may merely be a reflection of he fact that unionized/more highly organized sectors are contracting for reasons independent of union influence - an artifact of the data.

The estimations in Table 3 include the detailed industry dummies and show that larger plants and those with larger percentages of female employees continue to be less likely to fail. Establishments subject to a takeover appear more likely to close. Those with higher percentages of short-term contracts are also more likely to close, perhaps because such contracts indicate hard times at the plant. The addition of more detailed industry dummies adds to the explanatory power of the estimates as measured by the pseudo R-squared statistic. The role of unions identified earlier appears even more strongly. Indeed, it is not an exaggeration to claim that the positive influence of unions on plant closure is the most robust result. Moreover, the magnitudes in question are of economic interest. Table 4 presents projections from the estimate in the first column of Table 3. In the calculations, all explanatory variables are kept at their sample means with the exceptions of establishment size and union recognition. As shown, for small plants the increase in the probability of closure associated with union recognition for collective bargaining purposes is .071 percentage point, almost a 50 per cent increase. For large plants the increase is a very similar .067 , although this translates into a 65 percent rise in the probability of closure because of the reduced exposure of larger establishments to failure.

Picking up on our earlier evidence, and that of Machin (1995), that single plants may be less likely to close, Table 5 present results for separate samples defined according 
to whether or not the observation is part of a single or multi-establishment firm. ${ }^{7}$ The results in the second column of the table, pertaining to multi-establishment plants, reveal that larger establishments are indeed less likely to fail. Other findings are that plants with larger shares of part-time workers (perhaps proxying greater flexibility) are also less likely to close, while the incidence of short-time work and being involved in a takeover presage a higher likelihood of closure. Although establishments with a larger share of manual workers have a higher probability of closure, the same is apparently also true where there are higher proportions of the professional or technical workers. Again note that, despite the reduced degrees of freedom associated with use of a sub-sample, the union recognition coefficient estimate is even larger than before, as well as remaining highly statistically significant.

The above evidence contrasts with that provided for the, admittedly smaller, sample of single plant firms in the first column of Table 5. Here the presence of a joint consultative committee and compulsory redundancies are associated with an increased probability of closing. Importantly, the by now familiar effects of unions and of plant size both vanish. The coefficient estimate for each variable is now insignificantly different from zero and also opposite in sign when compared with plants that are part of multi-establishment firms.

We also estimated a fully-stacked model in which each control was interacted with a dummy variable identifying establishment status (as either a single establishment firm or part of a multi-establishment entity). This procedure allows us to reject the hypothesis that the estimates in the first two columns of Table 5 are identical (LR chisquared $(31)=44.74) . \quad$ Moreover, it allows us to easily identify those variables for 
which the point estimates are significantly different from each other as between the two types of establishment. The results are provided in the final column of Table 5. The most important finding is the difference between sectors in the influence of union recognition which is both large and precisely estimated. In addition to the differences identified earlier, observe that shift work has significantly greater influence in reducing closure in the multi-establishment sample, while the sharing of financial information has a significantly greater influence in reducing closure in the single establishment sample.

Note that this pattern of results is independent of the union variable we employ. In identical estimates that use the union coverage variable, we obtain a 'union' coefficient of -.0034 for the single establishment sub-sample, with a t-statistic of 0.669 . In sharp contrast, the corresponding coefficient estimate for the sub-sample of establishments that are part of multi-establishment entities is .0052, with a t-statistic of 3.493 .

As a final exercise, we offer a replication of the basic specification used by Machin (1995), in examining data from the earlier workplace surveys, with a view to establishing whether the specific variables he used in some way account for the profound differences in the British results. We have not heretofore presented that specification because it results in a particularly large reduction in sample size due to missing data on two critical variables, namely, below-average financial performance and operating well below full capacity. Moreover because of changes in the workplace survey, we can only obtain a measure of the latter variable for plants that are part of multi-establishment entities, leading to a further reduction in sample size. ${ }^{8}$ The first column of Table 6 presents results for a parsimonious specification which mimics that deployed by Machin (1995, Table A.1, col (3)) in containing the two new variables and replacing the broad 
industry controls with a single manufacturing-sector dummy variable. Two principal results emerge. First, establishments reporting superior financial performance emerge as less likely to close. Second, establishments recording considerable excess capacity are more likely to close. (Both results are also reported by Machin, although only the latter is statistically significant.) Third, and again most important, those establishments with union recognition remain significantly more likely to close with an estimated coefficient that is even larger than those already presented. Augmenting the explanatory variables and adding in the aggregate industry dummies - see the second and third columns of the table - does not materially alter any of these conclusions. The only new result that emerges within this reduced sample of multi-establishment plants is that rising levels of employee share ownership are now associated with a reduced likelihood of plant closure.

The bottom line is that, despite numerous iterations, the finding of a persistent and robust positive association between plant closings and union recognition/coverage for post-1990 Britain persists.

\section{Conclusions}

We have reported that British unions are associated with an increased probability of plant closings over the course of the 1990s. This finding is sharply at odds with prior research results for the United Kingdom and, less directly, for the United States. Moreover, the association is of considerable economic magnitude and is independent of which measure of unionism we employ and which treatment of industry effects we follow.

This central result is, however, driven by plants that are part of multiestablishment entities. Within single-establishment firms, no such effect is discernible. 
Thus, the coefficient estimate for the union measure(s) is negative and generally statistically insignificant for this sub-sample of establishments. We earlier argued that a union effect differentiated by establishment status is prima facie consistent with several strands of the theory reflecting game-theoretic considerations, insider-outsider distinctions, and incomplete information. But in line with piecemeal theoretical developments within this area, our arguments were ultimately informal and speculative. Nevertheless, the unions-cause-plant-closings hypothesis minimally requires some reformulation in the light of our single-establishment firm findings, especially if they are sustained in future empirical work.

There is of course the possibility that our results are very sensitive to the particular circumstances of time and place. We have noted that our sample period was preceded by a major legislative attack on union bargaining power. As is well known, between 1980 and 1990, five major pieces of union reform legislation were enacted by successive Conservative administrations. At one level, the attack on union immunities and might have been expected to curb union rent-seeking activity and mute any deleterious union effects on plant closings. Accordingly, we would expect Machin's results to carry over to the decade of the 1990s, which they clearly fail to do. But at another level, certain other aspects of the legislation may have operated in opposite fashion. First, the requirment for strike ballots may have led to a loss in union influence over employment in multi-establishment firms for the reasons identified by Manning (1993) and discussed earlier. Second, the weakening in union bargaining power implied by the legislation might have emboldened employers to close unionized establishments and either open new plants - that unions have largely failed to organize (see Disney, 
Gosling, and Machin, 1995, 1996) - or to expand their non-union operations in doublebreasted situations. In this endeavor, we would surmise that they are presumably guided by actual or, more likely in view of the collateral British findings reviewed in section 2 , future profitability considerations. (Again, we enter the caveat that profitability should be equated with the joint surplus of the enterprise.) The data limitation of being unable to identify the parent firm of multi-establishment plants precludes direct examination of these issues. Nonetheless, we think it entirely possible that the difference in results for Britain between Machin and ourselves has something to do with the sea change in the legislative framework confronting unionism in the last decade. The passage of New Labour's Employment Relations Act in 1998 marks another policy shift - this time in favor of unions - and provides a tantalizing opportunity to revisit the issue with further iterations of the WERS even if more fundamental progress perforce awaits better data sets and better theory. 


\section{Endnotes}

${ }^{1}$ But for the U.K. see the unpublished paper by Blanchflower and Oswald (1990), which points to significantly lower plant closings in industries with higher unionization rates.

And for the U.S., see Dunne and Roberts (1990).

2 Despite having detailed employment information on plants, Dunne and Macpherson do not have corresponding union data. The latter are obtained the May 1979 CPS and pertain to the union status of individuals, cross referenced by employer size (initial five intervals) and industry. This explains their grouping of plants into cells based on 74 three-digit CIC industries and 3 establishment size classes that form the sectoral aggregates.

3 Freeman and Kleiner also include (in two specifications) a measure of the extent of union wage concessions in the industry. The coefficient estimate for this concessions variable is positive albeit statistically insignificant.

4 Thus, the Los Angeles Times (1987, p. 29) reported that "spirits remain high" as General Motors closed a plant in Massachusetts in the late 1980s. The article emphasized that workers with high tenure received 30 weeks of unemployment benefits and 95 percent of take-home pay for two years.

${ }^{5}$ Our definition of survivors includes those establishments whose size had fallen below 25 , who had been subject to change in ownership and whose address had been changed.

${ }^{6}$ As mentioned, the results using union density are nearly identical. They are available from the author upon request.

${ }^{7}$ The division of the sample into two categories makes it impossible to retain the full disaggregated industry dummies. 
${ }^{8}$ The only difference in the two specifications is that our measure of financial performance is an index rather than the more parsimonious category of below average financial performance used by Machin. When we replaced the index with the latter measure, the coefficient estimate for financial performance was statistically insignificant (as for Machin) but the union results were largely unaffected 


\section{References}

Addison, John T., and Barry T. Hirsch. 1989. "Unions Effects on Productivity, Profits, and Growth: Has the Long Run Arrived? Journal of Labor Economics 7 (January): 72-105.

Addison, John T., and John B. Chilton. 1998. “Self-Enforcing Union Contracts:

Efficient Investment and Employment.” Journal of Business 71 (July): 349-369.

Becker, Brian E., and Craig A. Olson. 1992. "Unionization and Firm Profits.” Industrial Relations 31 (Fall): 395-415.

Blanchflower, David G., and Andrew J. Oswald. 1989. “The Determinants of Plant Closures." Mimeographed, University of Surrey and Centre for Labour Economics, London School of Economics.

Blanchflower, David G., Neil Millward, and Andrew J. Oswald. 1991. “Unionism and Employment Behaviour.” Economic Journal 101 (July): 815-834.

Bronars, Stephen G., and Doald R. Deere. 1993. 'Union Organizing Activity, Firm Growth, and the Business Cycle.” American Economic Review 83 (March): 203220.

Bronars, Stephen G., Donald R. Deere, and Joseph S. Tracy. 1994. “The Effects of Unions on Firm Behavior: An Empirical Analysis Using Firm-Level Data.” Industrial Relations 33 (October): 426-451.

Clark Kim B. 1984. “Unionization and Firm Performance: The Impact on Profits, Growth, and Productivity.” American Economic Review 74 (December): 893-919. 
Curme, Michael, and Lawrence M. Kahn. 1990. "The Impact of the Threat of Bankruptcy on the Structure of Compensation.” Journal of Labor Economics 8(October): $419-447$.

Denny, Kevin, and Stephen J. Nickell. 1992. "Unions and Investment in British Industry.” Economic Journal 102 (July): 874-887.

Disney, Richard, Amanda Gosling, and Stephen Machin. 1995. "British Unions in Decline - Determination of the 1980s Fall in Union Recognition." Industrial and Labor Relations Review 48 (April): 404-419.

Disney, Richard, Amanda Gosling, and Stephen Machin. 1996. “What Has Happened to Union Recognition in Britain?" Economica 63 (February): 1-18.

Dunne, Timothy, and David A. Macpherson. 1994. "Unionism and Gross Employment Flows.” Southern Economic Journal 60 (January): 727-738.

Dunne, Timothy, and Mark J. Roberts. 1990. “Wages and the Risk of Plant Closing.” Mimeographed, Department of Economics, Pennsylvania State University.

Fallick, Bruce C., and Kevin Hasset. 1999. "Investment and Union Certification.” Journal of Labor Economics 17 (July): 570 - 582.

Fernie, Sue, and David Metcalf. 1995. "Participation, Contingent Pay, Representation and Workplace Performance: Evidence from Great Britain.” British Journal of Industrial Relations 33 (September): 379-415.

Freeman, Richard B., and Morris M. Kleiner. 1999. “Do Unions Make Enterprises Insolvent?" Industrial and Labor Relations Review 52 (July): 510-527. 
Gerhart, Paul. 1987. Saving Plants and Jobs: Union-Management Negotiations in the Context of Threatened Plant Closing. Kalamazoo, Mich.: W.E. Upjohn Institute for Employment Research.

Grout, Paul A. 1984. "Investment and Wages in the Absence of Binding Contracts: A Nash Bargaining Approach.” Econometrica 52 (March): 449-460.

Hirsch, Barry T. 1991. Labor Unions and The Economic Performance of Firms. Kalamazoo, Mich.: W.E. Upjohn Institute for Employment Research.

Hirsch, Barty T. 1992. "Firm Investment Behavior and Collective Bargaining Strategy." Industrial Relations 31 (Winter): 95-121.

Karier, Thomas. 1985. "Unions and Monopoly Profits.” Review of Economics and Statistics 67 (February): 34-42.

Kuhn, Peter. 1986. “Wages, Effort, and Incentive Compatibility in Life-Cycle Employment Contracts.” Journal of Labor Economics 4 (January): 28-49.

Lazear, Edward P. 1983. “A Competitive Theory of Monopoly Unionism.” American Economic Review 71 (September): 606-620.

Lawrence, Colin, and Robert Z. Lawrence. “'Manufacturing Wage Dispersion: An End Game Interpretation.” Brookings Papers on Economic Activity 1: 47-106.

Leonard, Jonathan S. 1992. “Unions and Employment Growth.” Industrial Relations (Winter): 80-94.

Linneman, Peter D., Michael L. Wachter, and William H. Carter. 1990. 'Evaluating the Evidence on Union Wages and Employment.” Industrial and Labor Relations Review 44 (October): $34-53$.

Los Angeles Times. 1987. “Workers' Spirits Remain High as GM Prepares to Close 
Massachusetts Plant.” December 1, 1987: 29.

Machin, Stephen. 1995. "Plant Closures and Unionization in British Establishments." British Journal of Industrial Relations 33 (March) 55-68.

Machin, Stephen, and Mark Stewart. 1996. “Trade Unions and Financial Performance.” Oxford Economic Papers 48 (April): 213-241.

Manning, Alan. 1993. "Pre-Strike Ballots and Wage-Employment Bargaining." Oxford Economic Papers 45 (July): 422 - 429.

Menezes-Filho, Naercio, David Ulph, and John Van Reenen. 1998a. 'R\&D and Unionism: Comparative Evidence From British Companies and Establishments.” Industrial and Labor Relations Review 52 (October): 45-63.

Menezes-Filho, Naercio, David Ulph, and John Van Reenen. 1998b. “The

Determination of

R\&D: Empirical Evidence on the Role of Unions." European Economic Review 42 (May): 919-930.

Metcalf, David. 1993. “Industrial Relations and Economic Performance.” British Journal of Industrial Relations 31 (June): 255-83.

Metcalf, David. 1994. "Transformation of British Industrial Relations? Institutions, Conduct, and Outcomes." In Ray Barrell, ed., The U.K. Labour Market: Comparative Aspects and Institutional Developments. Cambridge, England: Cambridge University Press, pp. 126-157.

Millward, N., A. Bryson, and J. Forth. 2000. All Change at Work? British Employment Relations 1980-98, As Portrayed by the Workplace Industrial Relations Survey Series. London: Routledge. 
Oulton, Nicholas. 1990. "Labour Productivity in U.K. Manufacturing in the 1970s and 1980s." National Institute Economic Review 132 (May): 71-91.

Verma, Anil. 1985. "Relative Flow of Capital to Union and Nonunion Plants within a Firm.” Industrial Relations 24 (Fall): 395 - 405. 
Table 1: Descriptive Statistics of the Main Variables $(\mathrm{N}=1,326$ for variables without missing values)

\begin{tabular}{|c|c|c|c|}
\hline Variable & Mean & $\begin{array}{l}\text { Std. } \\
\text { Dev. }\end{array}$ & Definition \\
\hline Closed & 0.154 & 0.361 & Dummy $=1$ if the establishment closed by $1997 / 98$ \\
\hline $\begin{array}{l}\text { Union } \\
\text { recognition }\end{array}$ & 0.312 & 0.463 & $\begin{array}{l}\text { Dummy }=1 \text { if union recognized for collective } \\
\text { bargaining purposes }\end{array}$ \\
\hline $\begin{array}{l}\text { Union } \\
\text { coverage }\end{array}$ & 27.700 & 39.858 & $\begin{array}{l}\text { Percentage of employees covered by a collective } \\
\text { agreement }\end{array}$ \\
\hline Est. size & 4.132 & 0.753 & Log establishment size \\
\hline Est. age & 15.598 & 9.129 & Number of years operating at current address \\
\hline $\begin{array}{l}\text { Single est. } \\
\text { firm }\end{array}$ & 0.272 & 0.445 & Dummy $=1$ if single establishment firm \\
\hline $\begin{array}{l}\text { Percent } \\
\text { female }\end{array}$ & 37.138 & 28.808 & Percentage of female workers \\
\hline $\begin{array}{l}\text { Percent } \\
\text { manual }\end{array}$ & 54.139 & 33.694 & Percentage of manual workers \\
\hline $\begin{array}{l}\text { Percent } \\
\text { prof.-tech. }\end{array}$ & 13.458 & 20.626 & Percentage of professional / technical workers \\
\hline $\begin{array}{l}\text { Percent part- } \\
\text { time }\end{array}$ & 16.638 & 23.373 & Percentage of part-time workers \\
\hline Shift work & 0.344 & 0.475 & Dummy $=1$ if shift work practiced \\
\hline $\begin{array}{l}\text { Percent } \\
\text { short term }\end{array}$ & 0.086 & 0.280 & Percentage of short-term contract workers \\
\hline $\mathrm{JCC}$ & 0.206 & 0.405 & Dummy $=1$ if joint consultative committee present \\
\hline $\begin{array}{l}\text { New EI } \\
\text { schemes }\end{array}$ & 0.425 & 0.494 & $\begin{array}{l}\text { Dummy }=1 \text { if new employee involvement } \\
\text { schemes introduced during the past } 3 \text { years }\end{array}$ \\
\hline $\begin{array}{l}\text { Financial } \\
\text { disclosure }\end{array}$ & 0.569 & 0.495 & $\begin{array}{l}\text { Dummy=1 if financial information disclosed to } \\
\text { workers }\end{array}$ \\
\hline Climate & 0.927 & 0.260 & $\begin{array}{l}\text { Dummy }=1 \text { if industrial relations climate } \\
\text { good/very good }\end{array}$ \\
\hline ESOP & 10.507 & 23.777 & $\begin{array}{l}\text { Percentage of workers covered by share- } \\
\text { ownership schemes }\end{array}$ \\
\hline Layoffs & 0.141 & 0.348 & $\begin{array}{l}\text { Dummy }=1 \text { if compulsory redundancies invoked } \\
\text { in preceding year }\end{array}$ \\
\hline $\begin{array}{l}\text { Computer } \\
\text { tech. }\end{array}$ & 0.061 & 0.239 & $\begin{array}{l}\text { Dummy }=1 \text { if automated handling, storage, and } \\
\text { centralized machine control }\end{array}$ \\
\hline $\begin{array}{l}\text { Tech. } \\
\text { Change }\end{array}$ & 0.438 & 0.496 & $\begin{array}{l}\text { Dummy }=1 \text { if new plant/technology affecting jobs } \\
\text { introduced during preceding } 3 \text { years }\end{array}$ \\
\hline Takeover & 0.144 & 0.351 & $\begin{array}{l}\text { Dummy }=1 \text { if ownership change due to takeover } \\
\text { during the past } 3 \text { years }\end{array}$ \\
\hline Flexibility & 0.360 & 0.480 & $\begin{array}{l}\text { Dummy }=1 \text { if management implemented changes } \\
\text { to reduce job demarcation or increase the } \\
\text { flexibility of work }\end{array}$ \\
\hline
\end{tabular}




\begin{tabular}{|c|c|c|c|}
\hline $\begin{array}{l}\text { Market } \\
\text { Power }\end{array}$ & 0.267 & 0.443 & $\begin{array}{l}\text { Dummy=1 if firm dominates product market or } \\
\text { has few competitors }\end{array}$ \\
\hline Foreign & 0.074 & 0.262 & Dummy $=1$ if foreign ownership \\
\hline Export & 0.079 & 0.270 & $\begin{array}{l}\text { Dummy }=1 \text { if establishment produces primarily } \\
\text { for the export product }\end{array}$ \\
\hline $\begin{array}{l}\text { Unemploy- } \\
\text { ment }\end{array}$ & 6.665 & 1.804 & Regional unemployment rate (13 regions) \\
\hline $\begin{array}{l}\text { Manu- } \\
\text { facturing }\end{array}$ & 0.292 & 0.455 & Dummy $=1$ for manufacturing sector \\
\hline $\begin{array}{l}\text { Financial } \\
\text { performance }\end{array}$ & 1.505 & 0.604 & $\begin{array}{l}\text { Index of financial performance relative to } \\
\text { establishments in the same industry, where } \\
0=\text { below average; } 1=\text { about average; } 2=\text { above } \\
\text { average }\end{array}$ \\
\hline $\begin{array}{l}\text { Capacity } \\
\text { utilization }\end{array}$ & 0.068 & 0.252 & $\begin{array}{l}\text { Dummy }=1 \text { if capacity utilization is 'considerably } \\
\text { below average' }\end{array}$ \\
\hline
\end{tabular}


Table 2: Probit Regressions with One-digit Industry Dummies

(dependent variable: dummy=1 if establishment closed by 1997/98)

\begin{tabular}{|c|c|c|c|c|}
\hline \multicolumn{5}{|c|}{ Specification } \\
\hline & 1 & 2 & 3 & 4 \\
\hline \multicolumn{5}{|l|}{ Variable } \\
\hline \multirow{2}{*}{ Constant } & 0.128 & 0.151 & -0.269 & -0.237 \\
\hline & (0.356) & $(0.421)$ & $(0.535)$ & $(0.469)$ \\
\hline Union & $0.187 *$ & & $0.234 * *$ & \\
\hline recognition & (1.771) & & $(2.056)$ & \\
\hline Union & & $0.003 * *$ & & $0.003 * *$ \\
\hline coverage & & (2.336) & & $(2.555)$ \\
\hline \multirow[t]{2}{*}{ Est. size } & $-0.179 * *$ & $-0.185^{* *}$ & -0.109 & -0.113 \\
\hline & $(2.730)$ & $(2.813)$ & (1.424) & (1.475) \\
\hline \multirow[t]{2}{*}{ Est. age } & $0.5 \mathrm{E}-3$ & -0.001 & 0.001 & $0.4 \mathrm{E}-4$ \\
\hline & $(0.011)$ & $(0.162)$ & $(0.125)$ & $(0.008)$ \\
\hline Single est. & $-0.341 * *$ & $-0.333 * *$ & $-0.232^{*}$ & $-0.230^{*}$ \\
\hline firm & (3.023) & $(2.970)$ & (1.933) & (1.922) \\
\hline Percent & $-0.004^{* *}$ & $-0.004 * *$ & -0.003 & -0.002 \\
\hline female & $(2.305)$ & $(2.170)$ & (1.214) & (1.080) \\
\hline Percent & 0.002 & 0.002 & $0.005^{*}$ & $0.005^{*}$ \\
\hline manual & (1.079) & (0.963) & (1.910) & (1.829) \\
\hline Percent & & & 0.005 & 0.005 \\
\hline prof.-tech. & & & (1.433) & (1.408) \\
\hline Percent part- & & & -0.005 & -0.004 \\
\hline time & & & (1.601) & (1.546) \\
\hline Shift work & & & -0.130 & -0.149 \\
\hline & & & $(1.190)$ & (1.354) \\
\hline Percent & & & 0.175 & 0.171 \\
\hline short term & & & (1.132) & (1.101) \\
\hline \multirow[t]{2}{*}{$\mathrm{JCC}$} & & & -0.012 & $0.2 \mathrm{E}-3$ \\
\hline & & & $(0.097)$ & $(0.002)$ \\
\hline New EI & & & -0.061 & -0.067 \\
\hline schemes & & & $(0.605)$ & $(0.669)$ \\
\hline Financial & & & 0.021 & 0.013 \\
\hline disclosure & & & (0.198) & $(0.848)$ \\
\hline \multirow[t]{2}{*}{ Climate } & & & -0.112 & -0.108 \\
\hline & & & $(0.666)$ & $(0.642)$ \\
\hline \multirow[t]{2}{*}{ ESOP } & & & 0.001 & 0.001 \\
\hline & & & $(0.604)$ & $(0.597)$ \\
\hline \multirow[t]{2}{*}{ Layoffs } & & & 0.084 & 0.107 \\
\hline & & & $(0.667)$ & $(0.848)$ \\
\hline Computer & & & -0.128 & -0.111 \\
\hline tech. & & & $(0.632)$ & $(0.547)$ \\
\hline Tech. & & & -0.049 & -0.034 \\
\hline Change & & & $(0.460)$ & $(0.322)$ \\
\hline
\end{tabular}




\begin{tabular}{|c|c|c|c|c|}
\hline Takeover & & & $\begin{array}{c}0.202 \\
(1.622)\end{array}$ & $\begin{array}{c}0.203 \\
(1.622)\end{array}$ \\
\hline Flexibility & & & $\begin{array}{c}0.028 \\
(0.280)\end{array}$ & $\begin{array}{c}0.010 \\
(0.101)\end{array}$ \\
\hline Market & & & -0.023 & -0.012 \\
\hline power & & & $(0.222)$ & (0.111) \\
\hline Foreign & & & $\begin{array}{l}-0.073 \\
(0.402)\end{array}$ & $\begin{array}{c}-0.048 \\
(0.264)\end{array}$ \\
\hline Export & & & $\begin{array}{l}-0.219 \\
(1.184)\end{array}$ & $\begin{array}{l}-0.197 \\
(1.062)\end{array}$ \\
\hline $\begin{array}{l}\text { Unemploy- } \\
\text { ment }\end{array}$ & & & $\begin{array}{l}-0.017 \\
(0.649)\end{array}$ & $\begin{array}{l}-0.020 \\
(0.799)\end{array}$ \\
\hline $\begin{array}{l}9 \text { 1-digit } \\
\text { industry } \\
\text { dummies }\end{array}$ & Included & Included & Included & Included \\
\hline $\mathrm{N}$ & 1289 & 1285 & 1274 & 1270 \\
\hline Pseudo $\mathrm{R}^{2}$ & 0.061 & 0.064 & 0.073 & 0.076 \\
\hline $\begin{array}{l}\text { Log } \\
\text { Likelihood }\end{array}$ & -522.1 & -518.8 & -505.2 & -501.9 \\
\hline
\end{tabular}

Note: t-statistics in parentheses. $* *, *$ denote significance at the .05 and .10 levels, respectively. 
Table 3: Probit Regressions with Three-digit Industry Dummies (dependent variable: dummy=1 if establishment closed by 1997/98)

\begin{tabular}{|c|c|c|}
\hline & \multicolumn{2}{|c|}{ Specification } \\
\hline & 1 & 2 \\
\hline \multicolumn{3}{|l|}{ Variable } \\
\hline \multirow[t]{2}{*}{ Constant } & 0.377 & 0.151 \\
\hline & $(0.350)$ & $(0.421)$ \\
\hline Union & $0.304 * *$ & \\
\hline Recognition & (2.044) & \\
\hline Union & & $0.005 * *$ \\
\hline Coverage & & $(2.701)$ \\
\hline \multirow[t]{2}{*}{ Est. size } & $-0.153^{*}$ & $-0.162^{*}$ \\
\hline & (1.649) & (1.729) \\
\hline \multirow{2}{*}{ Est. age } & 0.002 & -0.001 \\
\hline & $(0.371)$ & $(0.177)$ \\
\hline Single est. & -0.203 & -0.184 \\
\hline Firm & (1.399) & (1.268) \\
\hline Percent & $-0.009 * *$ & $-0.009 * *$ \\
\hline Female & $(3.115)$ & $(2.940)$ \\
\hline Percent & $-0.6 \mathrm{E}-4$ & $-0.4 \mathrm{E}-3$ \\
\hline Manual & $(0.017)$ & $(0.141)$ \\
\hline Percent & 0.001 & 0.001 \\
\hline Prof.-tech. & $(0.287)$ & $(0.241)$ \\
\hline Percent & 0.006 & 0.006 \\
\hline Part-time & $(1.335)$ & (1.378) \\
\hline \multirow[t]{2}{*}{ Shift work } & -0.047 & -0.081 \\
\hline & $(0.325)$ & $(0.560)$ \\
\hline Percent & $0.396 * *$ & $0.387^{*}$ \\
\hline Short term & $(2.007)$ & (1.951) \\
\hline \multirow[t]{2}{*}{ JCC } & 0.073 & 0.073 \\
\hline & $0.480)$ & $(0.476)$ \\
\hline New EI & 0.025 & 0.024 \\
\hline Schemes & (0.198) & $(0.192)$ \\
\hline Financial & -0.021 & -0.034 \\
\hline Disclosure & $(0.163)$ & $(0.260)$ \\
\hline \multirow[t]{2}{*}{ Climate } & -0.232 & -0.236 \\
\hline & (1.198) & (1.217) \\
\hline \multirow[t]{2}{*}{ ESOP } & 0.003 & 0.003 \\
\hline & (1.179) & (1.234) \\
\hline \multirow[t]{2}{*}{ Layoffs } & 0.086 & 0.113 \\
\hline & $(0.549)$ & $(0.720)$ \\
\hline \multirow[t]{2}{*}{ Computer tech. } & 0.029 & 0.040 \\
\hline & $(0.119)$ & $(0.163)$ \\
\hline \multirow[t]{2}{*}{ Tech. change } & -0.039 & -0.026 \\
\hline & $(0.305)$ & $(0.208)$ \\
\hline
\end{tabular}




\begin{tabular}{lcc}
\hline Takeover & $0.258^{*}$ & $0.271^{*}$ \\
& $(1.660)$ & $(1.733)$ \\
Flexibility & 0.068 & 0.047 \\
& $(0.543)$ & $(0.368)$ \\
Market & -0.116 & -0.083 \\
Power & $(0.898)$ & $(0.641)$ \\
Foreign & -0.367 & -0.328 \\
& $(1.499)$ & $(1.357)$ \\
Export & -0.240 & -0.234 \\
& $(1.083)$ & $(1.051)$ \\
Unemployment & -0.051 & $-0.059^{*}$ \\
& $(1.628)$ & $(1.866)$ \\
93 3(4)-digit & Included & Included \\
industry dummies & & \\
$\mathrm{N}$ & 1211 & 1207 \\
Pseudo R & 0.227 & 0.232 \\
Log Likelihood & -418.148 & -414.298 \\
\hline Note: t-statistics in parentheses. $* * * *$ denote significance at the .05 \\
and .10 levels, respectively & &
\end{tabular}


Table 4: Projected Probabilities of Closure by Unionism and Establishment Size

\begin{tabular}{|c|c|c|}
\hline & Union recognition & No union recognition \\
\hline Small establishments & .230 & .159 \\
\hline Large establishments & .174 & .107 \\
\hline
\end{tabular}

Note: The calculations use the estimates from the first column of Table 3, setting all covariates other than establishment size and union recognition at their mean values. Small (large) size is defined as a value of one standard deviation below (above) the mean size. 
Table 5. Probit Regressions for Single vs. Multiple Establishment Firms (dependent variable: dummy=1 for establishment closed by 1997/98)

\begin{tabular}{|c|c|c|c|}
\hline Variable & $\begin{array}{c}\text { Single } \\
\text { establishment }\end{array}$ & $\begin{array}{c}\text { Multiple } \\
\text { establishment }\end{array}$ & Difference \\
\hline Constant & $\begin{array}{l}-2.626 \\
(1.394)\end{array}$ & $\begin{array}{l}-.0732 \\
(0.138)\end{array}$ & \\
\hline Union & -.7000 & $.3633^{* *}$ & $-1.063^{* *}$ \\
\hline Recognition & (1.241) & $(3.040)$ & $(2.429)$ \\
\hline Est. size & $\begin{array}{c}.2788 \\
(0.998)\end{array}$ & $\begin{array}{c}-.1686^{* *} \\
(2.079)\end{array}$ & $\begin{array}{l}.4474 * * \\
(1.988)\end{array}$ \\
\hline Est. age & $\begin{array}{c}.0064 \\
(0.365)\end{array}$ & $\begin{array}{l}-.0020 \\
(0.346)\end{array}$ & $\begin{array}{c}.0084 \\
(0.582)\end{array}$ \\
\hline $\begin{array}{l}\text { Percent } \\
\text { female }\end{array}$ & $\begin{array}{l}-.0008 \\
(0.534)\end{array}$ & $\begin{array}{l}-.0016 \\
(0.677)\end{array}$ & $\begin{array}{l}-.0024 \\
(0.444)\end{array}$ \\
\hline $\begin{array}{l}\text { Percent } \\
\text { Manual }\end{array}$ & $\begin{array}{l}-.0009 \\
(0.087)\end{array}$ & $\begin{array}{l}.0062 * * \\
(2.348)\end{array}$ & $\begin{array}{l}-.0071 \\
(0.910)\end{array}$ \\
\hline $\begin{array}{l}\text { Percent } \\
\text { prof.-tech. }\end{array}$ & $\begin{array}{c}.0067 \\
(0.365)\end{array}$ & $\begin{array}{l}.0058^{*} \\
(1.736)\end{array}$ & $\begin{array}{c}.0009 \\
(0.059)\end{array}$ \\
\hline $\begin{array}{l}\text { Percent part- } \\
\text { time }\end{array}$ & $\begin{array}{c}.0002 \\
(0.019)\end{array}$ & $\begin{array}{c}-.0073^{* *} \\
(2.292)\end{array}$ & $\begin{array}{c}.0075 \\
(0.876)\end{array}$ \\
\hline Shift work & $\begin{array}{c}.3169 \\
(0.836)\end{array}$ & $\begin{array}{l}-.1914 \\
(1.605)\end{array}$ & $\begin{array}{l}.5084 * \\
(1.664)\end{array}$ \\
\hline $\begin{array}{l}\text { Percent } \\
\text { short term }\end{array}$ & $\begin{array}{l}-.4049 \\
(0.713)\end{array}$ & $\begin{array}{l}.4034 * * \\
(2.426)\end{array}$ & $\begin{array}{l}-.8083^{*} \\
(1.764)\end{array}$ \\
\hline $\mathrm{JCC}$ & $\begin{array}{l}.8812 * \\
(1.946)\end{array}$ & $\begin{array}{l}-.1676 \\
(1.214)\end{array}$ & $\begin{array}{l}1.048 * * \\
(2.853)\end{array}$ \\
\hline $\begin{array}{l}\text { New EI } \\
\text { schemes }\end{array}$ & $\begin{array}{c}.2804 \\
(0.817)\end{array}$ & $\begin{array}{l}-.1563 \\
(1.419)\end{array}$ & $\begin{array}{c}.4366 \\
(1.553)\end{array}$ \\
\hline $\begin{array}{l}\text { Financial } \\
\text { disclosure }\end{array}$ & $\begin{array}{l}-.4105 \\
(1.164)\end{array}$ & $\begin{array}{l}.0985 \\
(0.866)\end{array}$ & $\begin{array}{l}-.5090^{*} \\
(1.762)\end{array}$ \\
\hline Climate & $\begin{array}{l}.1228 \\
(0.152)\end{array}$ & $\begin{array}{l}-.1126 \\
(0.690)\end{array}$ & $\begin{array}{c}.2353 \\
(0.376)\end{array}$ \\
\hline ESOP & $\begin{array}{l}-.0434 \\
(0.361)\end{array}$ & $\begin{array}{c}.0021 \\
(1.012)\end{array}$ & $\begin{array}{l}-.0454 \\
(0.510)\end{array}$ \\
\hline Layoffs & $\begin{array}{l}.8605^{* *} \\
(2.308)\end{array}$ & $\begin{array}{l}-.0614 \\
(0.426)\end{array}$ & $\begin{array}{l}.9218^{* *} \\
(2.904)\end{array}$ \\
\hline $\begin{array}{l}\text { Computer } \\
\text { tech. }\end{array}$ & $\begin{array}{l}-2.313 \\
(0.849)\end{array}$ & $\begin{array}{c}.0941 \\
(0.467)\end{array}$ & $\begin{array}{l}-2.404 \\
(1.184)\end{array}$ \\
\hline
\end{tabular}




\begin{tabular}{lccc}
\hline Tech. & -.0650 & -.0999 & -.0349 \\
Change & $(0.186)$ & $(0.873)$ & $(0.122)$ \\
Take over & -1.335 & $.2301^{*}$ & $-1.565^{*}$ \\
& $(1.215)$ & $(1.874)$ & $(1.895)$ \\
Flexibility & -.0194 & .0898 & -.1092 \\
& $(0.052)$ & $(0.842)$ & $(0.363)$ \\
Market & .0597 & .0324 & .0273 \\
Power & $(0.172)$ & $(0.279)$ & $(0.095)$ \\
Foreign & -.1002 & -.1834 & .0632 \\
& $(0.113)$ & $(1.002)$ & $(0.123)$ \\
Export & $-1.004^{*}$ & -.0902 & $-.9103 *$ \\
& $(1.638)$ & $(0.433)$ & .0279 \\
Unemploy- & .0036 & -.0243 & $(0.402)$ \\
ment & $(0.043)$ & $(0.884)$ & \\
9 1-digit & & & \\
industry \\
dummies
\end{tabular}

Note: t-statistics in parentheses. **, * denote significance at the .05 and .10 levels, respectively 
Table 6. Probit Regressions for Multiple Establishment Firms

(dependent variable: dummy=1 for establishment closed by 1997/98)

\begin{tabular}{|c|c|c|c|}
\hline \multicolumn{4}{|c|}{ Specification } \\
\hline Variable & Parsimonious & Augmented & Full \\
\hline Constant & $\begin{array}{l}-.2131 \\
(0.432)\end{array}$ & $\begin{array}{c}.3547 \\
(0.443)\end{array}$ & $\begin{array}{c}.5375 \\
(0.531)\end{array}$ \\
\hline $\begin{array}{l}\text { Union } \\
\text { recognition }\end{array}$ & $\begin{array}{l}.4776^{* *} \\
(3.053)\end{array}$ & $\begin{array}{l}.3565^{*} \\
(1.925)\end{array}$ & $\begin{array}{l}.4707 * * \\
(2.312)\end{array}$ \\
\hline Est. size & $\begin{array}{l}-.1128 \\
(1.006)\end{array}$ & $\begin{array}{l}-.0815 \\
(0.584)\end{array}$ & $\begin{array}{c}-.1364 \\
(0.934)\end{array}$ \\
\hline Est. age & $\begin{array}{l}-.0038 \\
(0.468)\end{array}$ & $\begin{array}{l}-.0087 \\
(0.923)\end{array}$ & $\begin{array}{l}-.0083 \\
(0.878)\end{array}$ \\
\hline $\begin{array}{l}\text { Percent } \\
\text { female }\end{array}$ & & $\begin{array}{l}-.0014 \\
(0.371)\end{array}$ & $\begin{array}{l}-.0007 \\
(0.163)\end{array}$ \\
\hline $\begin{array}{l}\text { Percent } \\
\text { manual }\end{array}$ & $\begin{array}{l}-.0024 \\
(1.041)\end{array}$ & $\begin{array}{l}.0081 * \\
(1.895)\end{array}$ & $\begin{array}{c}.0073 \\
(1.529)\end{array}$ \\
\hline $\begin{array}{l}\text { Percent } \\
\text { prof.-tech. }\end{array}$ & & $\begin{array}{l}.0037 \\
(0.618)\end{array}$ & $\begin{array}{c}.0038 \\
(0.616)\end{array}$ \\
\hline $\begin{array}{l}\text { Percent part- } \\
\text { time }\end{array}$ & . & $\begin{array}{c}-.0173^{* *} \\
(3.227)\end{array}$ & $\begin{array}{l}-.0173 * * \\
(3.037)\end{array}$ \\
\hline Shift work & & $\begin{array}{l}-.1655 \\
(0.844)\end{array}$ & $\begin{array}{c}.1536 \\
(0.769)\end{array}$ \\
\hline $\begin{array}{l}\text { Percent } \\
\text { short term }\end{array}$ & & $\begin{array}{r}.0794 \\
(0.263)\end{array}$ & $\begin{array}{l}-.0669 \\
(0.215)\end{array}$ \\
\hline $\mathrm{JCC}$ & & $\begin{array}{l}-.2980 \\
(1.325)\end{array}$ & $\begin{array}{l}-.2331 \\
(1.006)\end{array}$ \\
\hline $\begin{array}{l}\text { New EI } \\
\text { schemes }\end{array}$ & & $\begin{array}{l}-.0936 \\
(0.529)\end{array}$ & $\begin{array}{c}.0991 \\
(0.534)\end{array}$ \\
\hline $\begin{array}{l}\text { Financial } \\
\text { disclosure }\end{array}$ & & $\begin{array}{l}-.0114 \\
(0.062)\end{array}$ & $\begin{array}{l}-.0654 \\
(0.339)\end{array}$ \\
\hline Climate & & $\begin{array}{l}-.0425 \\
(0.149)\end{array}$ & $\begin{array}{c}.0493 \\
(0.162)\end{array}$ \\
\hline ESOP & & $\begin{array}{l}-.0093 * * \\
(2.546)\end{array}$ & $\begin{array}{c}-.0100 * * \\
(2.615)\end{array}$ \\
\hline
\end{tabular}




\begin{tabular}{|c|c|c|c|}
\hline Layoffs & & $\begin{array}{l}-.3484 \\
(1.384)\end{array}$ & $\begin{array}{l}-.3110 \\
(1.221)\end{array}$ \\
\hline $\begin{array}{l}\text { Computer } \\
\text { tech. }\end{array}$ & & $\begin{array}{l}-.0115 \\
(1.011)\end{array}$ & $\begin{array}{c}.3652 \\
(1.123)\end{array}$ \\
\hline $\begin{array}{l}\text { Tech. } \\
\text { Change }\end{array}$ & & $\begin{array}{l}-.1292 \\
(0.691)\end{array}$ & $\begin{array}{l}-.1544 \\
(0.785)\end{array}$ \\
\hline Takeover & & $\begin{array}{l}.0241 * \\
(0.130)\end{array}$ & $\begin{array}{l}-.0418 \\
(0.210)\end{array}$ \\
\hline Flexibility & & $\begin{array}{l}0.1138 \\
(0.643)\end{array}$ & $\begin{array}{l}.1490 \\
(0.816)\end{array}$ \\
\hline $\begin{array}{l}\text { Market } \\
\text { power }\end{array}$ & & $\begin{array}{l}-.1096 \\
(0.628)\end{array}$ & $\begin{array}{l}-.1579 \\
(0.860)\end{array}$ \\
\hline Foreign & & $\begin{array}{l}-.1001 \\
(0.388)\end{array}$ & $\begin{array}{l}-.0881 \\
(0.331)\end{array}$ \\
\hline Export & & $\begin{array}{c}.1142 \\
(0.400)\end{array}$ & $\begin{array}{l}-.0861 \\
(0.289)\end{array}$ \\
\hline $\begin{array}{l}\text { Unemploy- } \\
\text { ment }\end{array}$ & & $\begin{array}{l}-.0279 \\
(0.678)\end{array}$ & $\begin{array}{l}-.0464 \\
(1.060)\end{array}$ \\
\hline $\begin{array}{l}\text { Manu- } \\
\text { facturing }\end{array}$ & $\begin{array}{l}-.0143 \\
(0.081)\end{array}$ & $\begin{array}{l}-.2496 \\
(1.145)\end{array}$ & $\begin{array}{l}-.2003 \\
(1.038)\end{array}$ \\
\hline $\begin{array}{l}\text { Financial } \\
\text { performance }\end{array}$ & $\begin{array}{l}-.4013^{* *} \\
(3.402)\end{array}$ & $\begin{array}{c}-.5192 * * \\
(3.990)\end{array}$ & $\begin{array}{l}-.5987 * * \\
(4.274)\end{array}$ \\
\hline $\begin{array}{l}\text { Capacity } \\
\text { utilization }\end{array}$ & $\begin{array}{l}.7215^{* *} \\
(2.964)\end{array}$ & $\begin{array}{l}.7293^{* *} \\
(2.729)\end{array}$ & $\begin{array}{l}.7630^{* * *} \\
(2.788)\end{array}$ \\
\hline $\begin{array}{l}9 \text { 1-digit } \\
\text { Industry } \\
\text { Dummies }\end{array}$ & Not Included & Not Included & Included \\
\hline $\mathrm{N}$ & 458 & 451 & 451 \\
\hline Pseudo $\mathrm{R}^{2}$ & .0854 & .1685 & .1913 \\
\hline $\begin{array}{l}\text { Log } \\
\text { Likelihood }\end{array}$ & -200.6 & -181.5 & -178.1 \\
\hline
\end{tabular}

Note: t-statistics in parentheses. ${ }^{* *}, *$ denote significance at the .05 and .10 levels, respectively 


\section{IZA Discussion Papers}
No. Author(s)
280
P. Apps
R. Rees
281
G. Saint-Paul
282
J. Albrecht
A. Björklund
S. Vroman
283
M. Hagedorn
A. Kaul
V. Reinthaler

284

H. Rapoport

A. Weiss

285
J. Jerger
C. Pohnke
A. Spermann

286

M. Fertig

C. M. Schmidt

287

P. Guggenberger

A. Kaul

M. Kolmar

288

D. A. Cobb-Clark

289

L. Cameron

D. A. Cobb-Clark

290

D. A. Cobb-Clark

M. D. Connolly

C. Worswick

291
Title

Area

Date

Household Saving and Full Consumption over

7

04/01

the Life Cycle

Information Technology and the Knowledge

5

04/01

Elites

Is There a Glass Ceiling in Sweden?

5

04/01

Welfare Analysis in a Schumpeterian Growth

7

04/01

Model with Capital

The Optimal Size for a Minority

1

$04 / 01$

Gut betreut in den Arbeitsmarkt?

5

Eine mikroökonometrische Evaluation der

Mannheimer Arbeitsvermittlungsagentur

First- and Second-Generation Migrants in

Germany - What Do We Know and What Do

People Think

Efficiency Properties of Labor Taxation in a

3

$04 / 01$

Spatial Model of Restricted Labor Mobility

Getting Ahead: The Determinants of and Payoffs

5

04/01 to Internal Promotion for Young U.S. Men and Women

Old-Age Support in Developing Countries:

3

04/01

Labor Supply, Intergenerational Transfers and Living Arrangements

The Job Search and Education Investments of

1

04/01 Immigrant Families

Cohort Effects in the Educational Attainment of

1

05/01

Second Generation Immigrants in Germany:

An Analysis of Census Data 
N. Smith

L. Husted
G. Brunello
C. Lucifora
R. Winter-Ebmer

300
A. Stutzer
R. Lalive

301

J. R. Frick

G. G. Wagner

302

G. S. Epstein

A. Weiss

303

G. A. Pfann

B. F. Blumberg

304

P. Cahuc

E. Wasmer firm Bargaining 

H. Bonin
G. Abío
E. Berenguer
J. Gil
C. Patxot

307

G. A. Pfann

308

G. A. Pfann

D. S. Hamermesh

309

G. Brunello

310

U. Sunde

311

G. Brunello

312

C. Furnée

M. Kemler

G. A. Pfann

313

A. Ferrer-i-Carbonell

B. M.S. van Praag
Is the Deficit under Control? A Generational Accounting Perspective on Fiscal Policy and Labour Market Trends in Spain 

A. Frederiksen
E. K. Graversen
N. Smith

Works Councils and Collective Bargaining in 

A. Ibourk
B. Maillard

The Matching Efficiency of Regional Labour Models 
